\title{
Effect of Bio-Fertilizers Azotobacter chroococcum and Pseudomonas fluorescens on Growth of Broccoli (Brassica oleracea L. var. Italica)
}

\author{
Hussein Ali Salim ${ }^{1}$, Asaad Khanawi Aziz ${ }^{1}$, Majida Hadi Mahdi ${ }^{2}$, Mohammed Abdul Karim Ali ${ }^{1}$, \\ Muhannad Hakim Salman ${ }^{1}$, Mustafa Mohammed Hussein ${ }^{1}$, Latif Kamel Mohammed ${ }^{1}$, \\ Mohammed Shehab Ahmed ${ }^{1}$, Ayad Yousef Khalil ${ }^{1}$, Tami Ayal Hadi ${ }^{1}$ \\ ${ }^{1}$ Directorate of Diyala Agriculture, Ministry of Agriculture, Iraq \\ ${ }^{2}$ College of Science, University of Baghdad, Iraq \\ Corresponding author: Hussein Ali Salim
}

\begin{abstract}
A field experiment was carried out at the experimental farm of soil laboratory belong to Directorate of Diyala Agriculture, Iraq during 2017. The experiment comprises of different doses of biofertilizers (Azotobacter chroococcum and Pseudomonas fluorescens) $0.08,0.14$ and 0.28 $\mathrm{g} /$ plant to assess their performance on growth characteristics of broccoli. The experiment was laid out in randomized complete block design having four treatments with three replications. The data analysis revealed that the maximum of leaves numbers in the treatment of Biofertilizer, 0.28 (23.4) whereas the maximum area of bigger leaf and head diameter was recorded in all treatments of Biofertilizer $0.08,0.14$ and $0.28(415.9,340.3$ and $373.9 \mathrm{~cm})$ and $(15.5,15.4$ and $15.1 \mathrm{~cm})$ as compared with control $(108.8 \mathrm{~cm})$ and $(3.0 \mathrm{~cm})$ respectively.
\end{abstract}

Key words: Broccoli, Azotobacter chroococcum, Pseudomonas fluorescens.

Date of Publication: 2018-08-30

DOI: https://doi.org/10.24297/jab.v11i1.7590

ISSN: 2347-6893

Volume: 11 Issue: 01

Journal: Journal of Advances in Biology

Publisher: CIRWORLD

Website: https://cirworld.com

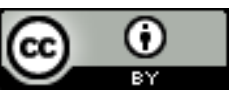

This work is licensed under a Creative Commons Attribution 4.0 International License. 


\section{Introduction}

The broccoli (Brassica oleracea var. Italica) belongs to the family Brassicaceae or Cruciferae, it is one of the most nutritious vegetables among the crops, it is considered food important due to its high nutritional value Because it contains vitamin A and c, protein, carotenoids, fiber, calcium, folic acid and anti-carcinogenic compounds. Is richer Source of sulforaphane, a compound reduce the risk of cancer in humans [1;2]. Potential of crop production is increases by synthetic fertilizers but excessive use of these fertilizers causes imbalance in soil environment, bio fertilizers have proven best for soil fertility and productivity [3]. Nutrient management is the main factor, which affects the productivity and quality of any crop, Bio fertilizers are improving quality and quantity of vegetable produce through they contain microorganisms which are capable of mobilizing nutrient elements from unavailable form to available form through different biological processes [ 4]. Azotobacter is aerobic bacteria and heterotrophic, it has the ability to fix nitrogen nonsymbiotically and existed in soils and water $[5 ; 6 ; 7 ; 8]$. It has capability of synthesizing antibiotics, plant growth promotion substances, exopolysaccharides, vitamins and pigment production $[9 ; 10$; $11 ; 12 ; 13 ; 14]$. It has the ability to solubilize phosphates in aquaculture systems and antagonist effect against pathogens $[15 ; 16 ; 17 ; 18]$. Pseudomonas is associated with the rhizosphere and is able to exert a beneficial effect on plant growth [19]. Pseudomonas fluorescens is considered to be the most promising group for plant growth [20]. This study was carried out to evaluate Azotobacter chroococcum and Pseudomonas fluorescens on the growth of broccoli.

\section{Materials and Methods}

The present experiment was conducted at farm of soil laboratory belong to Directorate of Diyala Agriculture, Iraq during 2017. The Broccoli seedlings were obtained from nursery of Directorate of Diyala Agriculture and transplanted in the soil with Ec $0.81 \mathrm{dsm}$ and PH 7.13 at 19\9\2017. Bio fertilizer (Azotobacter chroococcum \& Pseudomonas fluorescens) as commercial formulation was obtained from a ministry of science and technology. DAP fertilizer (Diammonium phosphate) at the rate of $100 \mathrm{~kg} \backslash$ hectare was added at 29/9/2017 whereas bio fertilizers were added to each plant by drill the soil close the plant and deep $5 \mathrm{~cm}$ at 18/10/2017, the experiment included three levels of bio fertilizers $0.08,0.14$ and $0.28 \mathrm{~g} /$ plant with a treatment of control without adding with three replications, the distance between row to row and plant to plant was kept as $40 \mathrm{~cm} \times 20 \mathrm{~cm}$ respectively, ten plants of each replicate were taken randomly for recording vegetative growth characteristics, (i.e., number of leaves, the area of the bigger leaf, length of head, a diameter of the head, length of a plant, head weight, plant weight, head weight ton/acre, plant weight ton/acre. The experiment was conducted under Randomized Block Design and watered as needed and the data was analyzed by one-way analysis of variance (ANOVA) [21].

\section{Results and Discussion}

The data of growth characteristics viz., numbers of leaves, area of bigger leaf and diameter of head revealed that significant variations among the different treatments under study (Table 1 ). The maximum of leaves numbers was superior in the treatment of Biofertilizer, 0.28 (23.4) followed by Biofertilizer 0.08 (21.9) and Biofertilizer 0.14 (21.3) as compared with control (17.9).The maximum area of bigger leaf and head diameter was recorded in all treatments of Biofertilizer $0.08,0.14$ and $0.28(415.9,340.3$ and $373.9 \mathrm{~cm})$ and $(15.5,15.4$ and $15.1 \mathrm{~cm})$ with significant variations from control $(108.8 \mathrm{~cm})$ and $(3.0 \mathrm{~cm})$ respectively, whereas the other characteristics showed non-significant variation in spite of the yield of plant and head was high in all biofertilizers as compared with control. 
The present findings are in agreement with the results of $[22 ; 23 ; 24]$ stated that application of biofertilizers (Azotobacter and Phosphorus solublising bacteria) with NPK led to the effective utilization of nutrients available in the soil which increased growth and activity of microbial saprophytes which influenced the yield of broccoli per hectare. [25] reported that application of biofertilizer such Azotobacter helps in secretion of substances of growth promotion which leads to uptake and decomposition of nutrients, transportation of water through root development. [26] reported that the increase in the number of broccoli leaves per plant due to the application biofertilizers (Azotobacter) with a combination of NPK might have increased the availability of nutrients through direct addition in the soil. phosphorus solubilizing bacteria (PSB) like P. fluorescens can be implemented for broccoli cultivation, $P$. fluorescens has the ability to increase growth, nutrient uptake, and yield of broccoli [ 27]. P. fluorescens has the ability to produce plant growth promoting substances and some secondary metabolites which enhance nutrient uptake and plant growth [28].

\section{Conclusion}

The benefits of growth-promoting microbes such as $A$. chroococcum in combination with $P$. fluorescens in the present study was clearly demonstrated to be a promising factor for improved growth performance, nutrition, and increase in plants growth of broccoli and sustain yield.

\section{Conflict of Interest}

The authors declare that they have no competing interests.

\section{Acknowledgements}

Authors wish to thank Ministry of Agriculture, Directorate of Diyala Agriculture for awarding the opportunity to accomplish this work.

Table 1. Effects of bio fertilizers on some characteristics of broccoli

\begin{tabular}{|c|c|c|c|c|c|c|c|c|c|}
\hline Treatments & $\begin{array}{l}\text { Numbers } \\
\text { of leaves }\end{array}$ & $\begin{array}{c}\text { Area } \\
\text { of } \\
\text { bigger } \\
\text { leaf } \\
\text { (cm) }\end{array}$ & $\begin{array}{l}\text { Head } \\
\text { height } \\
(\mathrm{cm})\end{array}$ & $\begin{array}{l}\text { Diameter } \\
\text { of head } \\
(\mathrm{cm})\end{array}$ & $\begin{array}{l}\text { plant } \\
\text { height } \\
\text { (cm) }\end{array}$ & $\begin{array}{l}\text { Head } \\
\text { weight } \\
\text { (g) }\end{array}$ & $\begin{array}{c}\text { Plant } \\
\text { weight } \\
(g)\end{array}$ & $\begin{array}{c}\text { Head } \\
\text { yield } \\
\text { ton/acre }\end{array}$ & $\begin{array}{c}\text { Plant } \\
\text { yield } \\
\text { ton/acre }\end{array}$ \\
\hline $\begin{array}{c}\text { Biofertilizer } \\
0.08 \\
\text { g/plant }\end{array}$ & 21.9 & 415.9 & 17.1 & 15.5 & 59.9 & 297.2 & 1028.6 & 2.477 & 8.571 \\
\hline $\begin{array}{c}\text { Biofertilizer } \\
0.14 \\
\text { g/plant } \\
\end{array}$ & 21.3 & 340.3 & 17.9 & 15.4 & 60.3 & 281.1 & 842.2 & 2.343 & 7.018 \\
\hline $\begin{array}{c}\text { Biofertilizer } \\
0.28 \\
\text { g/plant }\end{array}$ & 23.4 & 373.9 & 17.9 & 15.1 & 58.5 & 283.5 & 890.7 & 2.362 & 7.422 \\
\hline Control & 17.9 & 239.0 & 16.7 & 11.2 & 52.3 & 158.2 & 543.9 & 1.222 & 4.301 \\
\hline$C D(0.05)$ & 1.3 & 108.8 & N.S & 3.0 & N.S & N.S & N.S & N.S & N.S \\
\hline
\end{tabular}




\section{References}

1. Thamburaj S. and Singh N. (2001). Textbook of Vegetables, Tubercrops and Spices. ICAR. New Dehli. 469p.

2. Michaud, D. S., P. Pietnen, R. R. Taylor, M. Virtanen, J. Vitramo and D. Albanes (2002). Intakes of fruits and vegetables, carotenoids and vitamins $A, E, C$ in relation to the risk of bladder cancer in the ATBC cohort study. Br. J. Cancer, 87: 960-965.

3. Prince Kumar, MI Bhardwaj, Dharminder Kumar, Ramesh Kumar, D Tripathi, Ks Thakur, N Bharat, Nidhish Gautam, Sandeep Kumar And Balbir Dogra, (2017).Comparative performance of organic and inorganic fertilizers on plant growth, head yield, soil health and severity of black rot in sprouting broccoli cv Green Head, International Journal of Farm Sciences 7(1): 69-76.

4. Negi Ekta, Punetha Shailaja, Pant S.C., Kumar Sandeep, Bahuguna Pankaj, Mekap Bengia and Nautiyal B.P. (2017). Effect of organic manures and bio-fertilizers on growth, Yield, quality and economics of broccoli (brassica oleracea I. Var. Italica plenck) cv. Green head under high-hill conditions of uttarakhand, International Journal of Advanced Biological Research, VOL.7 (1): 96 100.

5. Becking, J. (2006). The family Azotobacteraceae. Prokaryotes. 6, 759- 783.

6. Setubal, J.; Dos Santos, P.; Goldman, B.; Ertesvåg, H.; Espin, G.; Rubio, L.; Valla, S.; Almeida, N.; Balasubramanian, D.; Cromes, L.; Curatti, L.; Du, Z.; Godsy, E.; Goodner, B.; Hellner-Burris, K.; Hernandez, J.; Houmiel, K.; Imperial, J.; Kennedy, C.; Larson, T.; Latreille, P.; Ligon, L.; Lu, J.; Mærk, M.; Miller, N.; Norton, S.; O'Carroll, I.; Paulsen, I.; Raulfs, E.; Roemer, R.; Rosser, J.; Segura, D.; Slater, S.; Stricklin, S.; Studholme, D.; Sun, J.; Viana, C.; Wallin, E.; Wang, B.; Wheeler, C.; Zhu, H.; Dean, D.; Dixon, R.; Wood. D. (2009). Genome sequence of Azotobacter vinelandii, an obligate aerobe specialized to support diverse anaerobic metabolic processes. J. Bacteriol. 191, 4534-4545.

7. Tejera, N.; Lluch, C.; Martínez, M.; González, J. (2005). Isolation and characterization of Azotobacter and Azospirillum strains from the sugarcane rhizosphere. Plant Soil. 27, 223-232.

8. Torres, M.; Valencia, S.; Bernal, J.; Martínez, P. (2000). Isolation of Enterobacteria, Azotobacter sp. and Pseudomonas sp., producers of indole-3-acetic acid and siderophores, from Colombian rice rhizosphere. Rev. Latin. Microbiol. 42, 171-176.

9. Mantilla, J. (2008). Distribución y capacidad fijadora de nitrógeno de bacterias diazótrofos aisladas en suelos del sur del trapecio Colombiano.155p. (M.Sc. Dissertation. Science Faculty. Pontificia Javeriana University).

10. Pandey, A.; Kumar, S. (1990). Inhibitory effects of Azotobacter chroococcum and Azospirillum brasiliense on a range of rhizosphere fungi. Indian J. Exp. Biol. 28, 52-54.

11. Pandey, A.; Sharma, E.; Palni, L. (1998). Influence of bacterial inoculation on maize in upland farming systems of the Sikkim Himalaya. Soil. Biol. Biochem. 30, 379-384.

12. Salmeron, V.; Martinez, M.V.; Gonzalez, J. (1990). Nitrogen fixation and production of auxins, gibberellins and cytokinin by Azotobacter chroococcum strain isolated from root of Zea mays in presence of insoluble phosphate. Chemosphere. 20, 417-422.

13. Cuesta, A. (2006). Estrategias de cultivo en la producción de alginates por Azotobacter vinelandii. Medellín, Colombia, 105p. (M.Sc. Dissertation. National University of Colombia). 
14. Sabra, W.; Zeng, A.; Deckwer, W. (2001). Bacterial alginate: physiology, product quality and process aspects. Appl. Microbiol. Biotechnol. 56, 315-325.

15. Faccini, G.; Garzon, S. (1996). Evaluación del efecto de un inóculo dual de bacterias solubilizadoras de fosfato y Azotobacter chroococcum en el cultivo de papa "criolla" yema de huevo (Solanum phureja). Bogotá, Colombia, 97p. (Bacteriology Undergraduate. Dissertation. Science Faculty. Pontificia Javeriana University).

16. Garg, S.; Bhatnagar, A.; Kalla, A.; Narula, N. (2001). In vitro nitrogen fixation, phosphate solubilization, survival and nutrient release by Azotobacter strains in an aquatic system. Bioresour. Technol. 80, 101- 109.

17. Kumar, V.; Singh, K. (2001). Enriching vermicompost by nitrogen fixing and phosphate solubilizing bacteria. Bioresour. Technol. 76, 173-175.

18. Sudhir, U.; Meshram.; Jager, G. (1983). Antagonism of Azotobacter chroococcum isolates to Rhizoctonia solani. Eur. J. Plant Phatol. 89, 191-197.

19. Tilak KV, Ranganayaki N, Pal KK, De R, Saxena AK, Nautiyal CS, Mittal S Tripathi AK, Johri BN (2005). Diversity of plant growth and soil health supporting bacteria. Curr. Sci. 89(1):136-150.

20. Sivasakthi S., Usharani G. and Saranraj P., (2014). Biocontrol potentiality of plant growth promoting bacteria (PGPR) - Pseudomonas fluorescens and Bacillus subtilis: A review, African Journal of Agricultural Research, Vol. 9(16), pp. 1265-1277.

21. Fisher RA, Yates, (1968). Statistical method for research workers. Oliver and boyd Itd.

Edinburgh and London, 10.

22. Sharma A, Parmar DK, Kumar P, Singh Y and Sharma RP (2008). Azotobacter soil amendment integrated with cow manure reduces need for NPK fertilizers in sprouting broccoli. International Journal of Vegetable Science 14(3): 273-285.

23. Singh AK and Singh A (2000). Influence of nitrogen and potassium on growth and head yield of broccoli (Brassica oleracea L var italic L Plenck) under low hills subtropical condition of HP. Vegetable Science 27(1): 99-100.

24. Sharma KC (2000). Influence of integrated nutrient management on yield and economics in broccoli (Brassica oleracea L var italica Plenck) cv Green Head under cold temperate conditions. Vegetable Science 27(1): 62-63.

25. Bhardwaj AK, Kumar P and Singh RK (2007). Response of nitrogen and pre-planting treatment of seedlings with the Azotobacter on growth and productivity of broccoli (Brassica oleracea var italica). Asian Journal of Horticulture 2(1): 15-17.

26. Yadav LP, Kavita A and Maurya IB (2012). Effect of nitrogen and biofertilizers on growth of cabbage (Brassica oleracea var capitata L) var Pride of India. Progressive Horticulture 44(2): 318320.

27. Anju Tanwar, Ashok Aggarwal, Sunita Kaushish and Sonika Chauhan,(2013). Interactive effect of AM Fungi with Trichoderma viride and Pseudomonas fluorescens on growth and yield of Broccoli, Plant Protect. Sci. Vol. 49, No. 3: 137-145.

28. Burr T.J., Schroth M.N., Suslow T.V. (1978). Increased potato yields by treatment of seed pieces scientific strains of Pseudomonas fluorescens and P. putida. Phytopathology, 68: 1377-1383. 